Egyptian Journal of Aquatic Biology \& Fisheries

Zoology Department, Faculty of Science,

Ain Shams University, Cairo, Egypt.

ISSN $1110-6131$

Vol. 25(3): $329-338$ (2021)

www.ejabf.journals.ekb.eg

\title{
The Effect of Acid Solvent on the Physicochemical Characteristics of Tuna Dark
} Meat Fish Meal

\author{
Vanessa Lekahena ${ }^{1}$, Sandra Hiariey ${ }^{2}$ and Zubair Saing ${ }^{3}$; \\ ${ }^{1}$ Faculty of Agriculture, Universitas Muhammadiyah Maluku Utara, Ternate, Indonesia \\ ${ }^{2}$ Faculty of Teacher Training and Education, Universitas Darussalam Ambon, Indonesia \\ ${ }^{3}$ Faculty of Engineering, Universitas Muhammadiyah Maluku Utara, Ternate, Indonesia \\ "Corresponding Author: zubairsaing@ummu.ac.id
}

\section{ARTICLE INFO \\ Article History: \\ Online: May 29, 2021 \\ Keywords: \\ Dark meat, \\ Tuna fish, \\ physicochemical \\ characteristics, \\ acid solvent}

Received: April 2, 2021

Accepted: April 30, 2021

\begin{abstract}
Tuna dark meat can be processed into fish meal to increase its economic value and shelf life. Fish meal is a high-protein, low-moisture product derived from fish parts or a fish grinding mill. This study was organized to discover the effect of an acid solvent on the physicochemical properties of tuna dark meat in fish meal. The results of the study revealed that the extraction of tuna dark meat using acid solvent types affected the physicochemical characteristics of the produced fish meal in all test parameters, including yield value, bulk density, whiteness, $\mathrm{pH}$, moisture content, ash, protein, fat, and total plate count. The best characteristics of fish meal were those extracted using lime acid (AJ); with a yield value of $26.230 \%$, bulk density of $0.937 \mathrm{~g} . \mathrm{ml}^{-1}$, whiteness of $33.967 \%$, $\mathrm{pH}$ of 3.6, moisture content of $6.257 \%$, ash of $4.674 \%$, protein of $78.077 \%$, fat of $1.938 \%$, and total plate count of $1.79 \times 10^{3} \mathrm{cfu}^{-\mathrm{g}^{-1}}$. This finding serves as a model for the processing of tuna meat as an innovation in providing healthy and nutritious food for fish consumption.
\end{abstract}

\section{INTRODUCTION}

The different methods of fish processing may result in different waste potential and quality (Bragadottir et al., 2007). Solid waste resulted from tuna fish processing in the form of fish bones, fins, scales, and dark meat of about 20-30\% from the total fish was not optimally utilized. Fish dark meat is a meat layer found in the whole fish lower body part under scales, approximately $2-20 \%$ depending on the fish species and size, containing myoglobin, hemoglobin and high in fat. Stone (2007) stated that tuna loin processing resulted in waste of approximately $37.1 \%$ and dark meat of $17.9 \%$. That waste was not commonly utilized or was merely used for animal feed making, yet in fact fish dark meat has essential components that might be used as nutritional sources in food processing.

Karunaratha and Attygalle (2010) stated that tuna dark meat had the moisture content of $70.83 \%$, protein of $20.22 \%$, fat of $1.01 \%$, and ash of $0.92 \%$, besides other compositions, such as SFA of $22.74 \%$, MUFA of $21.11 \%$ and PUFA of $55.85 \%$. 
Meanwhile, Sánchez-Zapata et al. (2011) mentioned that mineral content of Fe was $32.11 \mathrm{mg}$ or $73.38 \%$ of the total mineral content with high bio-viability, water binding power of $8.37 \mathrm{~g}$ water. $\mathrm{g}^{-1}$, and oil holding capacity of $8.11 \mathrm{~g} \mathrm{oil.g} \mathrm{g}^{-1}$.

Tuna dark meat had peroxide compounds of $80 \%$ in the form of myoglobin and hemoglobin composed of myosin, globin, and heme structure (Okada, 1990). Myoglobin content in tuna dark meat was approximately $9650.12 \mathrm{mg} / \mathrm{kg}$ (Sánchez-Zapata et al., 2011) that it might easily result in rancidity, decreasing quality, and when processed, it was not well accepted by some individuals due to its taste, color, and odor (Okada, 1990

; Bertoldi et al., 2004). The utilization of fish dark meat into fish meal is one alternative solution to improve the economic value, storage time, and meat quality that the society may well accept and have the potential as animal protein source in food processing.

Fish meal is one utilization form of fish waste or fish parts which fat is separated, dried, and grinded to produce protein, mineral, and vitamin-rich fish meal. Good quality fish meal is that with the same particle size, free from fish bones, fish eyes, foreign materials, brighter color, and fish-like odor (Afrianto \& Liviawaty, 2005).

Fish meal making can be done by using wet, dry, and distillation methods. Dry method is the simplest method with low cost, yet the fish meal quality is also poor. Wet method may be conducted with extraction through boiling process in either acid or alkali solution using autoclave, dried, and flouring. This method may result in better quality of fish meal when compared to that made with dry method. The extraction process in this research was conducted using acid solvent, namely acetic acid and lime acid since according to the research conducted by Immaculate $\boldsymbol{e t}$ al. (2013), that extraction using acetic acid solvent at the temperature of $70{ }^{\circ} \mathrm{C}$ for 30 minutes had the function to lose the fat and whitens the dark meat.

This research aimed at revealing the effect of acid solvent on the physicochemical characteristics of fish meal from tuna dark meat, while its utilization is achieved by minimizing the waste resulted from tuna processing in the form of processed product diversification in the form of fish meal.

\section{MATERIALS AND METHODS}

\section{Materials and Equipment}

The material used was tuna dark meat already cleaned from its scales, bones, and other unused parts from the tuna loin industrial processing in Bastiong market, Ternate, Indonesia. The other additional materials were technical $\mathrm{NaCl}$, distilled water, acetic acid, citric acid and lime acid with the concentration of 5\%. The materials used for analysis were buffer solution to measure $\mathrm{pH}$, solution and other chemical materials to test the content of protein, fat and total plate count.

The equipment used in this research consisted of knife, grinder, plastic containers, digital scale, boiling pot, stirring spatula, measuring glass, stove, drying oven, termometer, timer, disc mill and stationaries for the fish meal making process. The equipment used for analysis included vacuum oven, furnace oven, $\mathrm{pH}$ meter, whiteness meter, analytic scale, destruction equipment, titration, soxhlet flask, glass equipment, desiccator, petri disk and other equipment for proximate and microbiological analysis. 


\section{Fish meal processing}

The fish meal making process was conducted through some steps. First, the tuna dark meat was washed using clean running water to get rid of the fish dirt, slime, and blood. Second, the cleaned tuna dark meat was then grinded using grinder and washed once again using the solution of $\mathrm{NaCl} 2 \%$. Third, the tuna dark meat was then extracted using acid solvent types as follows: AA (acetic acid 5\%); AS (citric acid 5\%); AJ (lime acid 5\%) and AQ (distilled water, control), with the solvent and tuna dark meat ratio of $3: 1$, in the temperature of $100{ }^{\circ} \mathrm{C}$ for \pm 20 minutes. The tuna dark meat resulted from the extraction was then filtered, cold, dried using a drying oven in the temperature of $50{ }^{\circ} \mathrm{C}$ for \pm 48 hours up to the water content that was $<12 \%$, and then grinded using disc mill and sieved with the mesh size of 100 .

\section{Characterization of fish meal}

The characterization of fish meal procedures included yield, bulk density, whiteness level, $\mathrm{pH}$ value, proximate and total plate count test. Yield was based on the simultaneous weight ratio of fish meal and fish dark meat. Bulk density was the sample weight per material volume (Singh et al., 2005). Whiteness level was measured with whiteness meter (Lanier et al. 1991). The $\mathrm{pH}$ value was determined with $\mathrm{pH}$ meter, while the proximate analysis included the moisture content measured with gravimetric method (AOAC, 2005); ash content measured with gravimetric method (AOAC, 2005); protein content measured with ash micro method of kjeldahl (AOAC, 2005), fat content measured with fat shoxlet (AOAC, 2005), and total plate count (TPC)was determined using BSN (2015).

\section{Experimental design and statistical analysis}

This research was conducted using a single-factor completely randomized design with three repetitions in each treatment. The data resulted from the physicochemical test was analyzed using SPSS 22.0 program for single-factor Anova at significant range of $95 \%$ and if the test result was significantly different, Duncan Multiple Range Test (DMRT) was further conducted.

\section{RESULTS AND DISCUSSIONS}

Fish meal is a product containing protein, mineral and vitamin, produced from the fish meat by extracting its fat and liquid. The fish meal's nutritional content depended on the fish type used as the raw material (Martinez et al., 1998). The fish meal's characterization in this research included: determining yield, bulk density, whiteness, $\mathrm{pH}$ value, proximate (moisture content, ash, protein and fat) and total plate count, as presented in Table (1). The utilization of SNI 01-2715-1992 on fish meal quality was to compare the fish meal making stages and its quality to meet the commercial fish meal quality standard as presented in Table (2).

\section{Yield}

Calculation of the yield was conducted to determine the economic value and effectiveness of a material determined based on the percentage ratio between the fish meal initial and final weight. The greater the yield value of a product, the higher is the economic value of that product. The yield values of fish meal were as follows: $22.193 \%$ 
(AQ); $21.910 \%$ (AS); $26.230 \%$ (AJ) and $27.077 \%$ (AA), with the highest fish meal value of AA and the lowest one of AS (Table 1).

Table 1. Physicochemichal characteristics of fish meal (g/100 g sample)

\begin{tabular}{lcccc}
\hline \multicolumn{1}{c}{$\begin{array}{c}\text { Physicochemichal } \\
\text { characteristics }\end{array}$} & \multicolumn{4}{c}{ Treatment } \\
\cline { 2 - 5 } & $\mathbf{A Q}$ & $\mathbf{A S}$ & $\mathbf{A J}$ & $\mathbf{A A}$ \\
\hline Yield (\%) & $22.193^{\mathrm{a}}$ & $21.910^{\mathrm{a}}$ & $26.230^{\mathrm{b}}$ & $27.077^{\mathrm{b}}$ \\
Bulk density (g/mL) & $0.867^{\mathrm{b}}$ & $0.037^{\mathrm{a}}$ & $0.937^{\mathrm{c}}$ & $0.933^{\mathrm{c}}$ \\
Whiteness (\%) & $22.333^{\mathrm{a}}$ & $29.900^{\mathrm{b}}$ & $33.967^{\mathrm{c}}$ & $30.200^{\mathrm{b}}$ \\
pH value & $5.267^{\mathrm{c}}$ & $2.500^{\mathrm{a}}$ & $3.600^{\mathrm{b}}$ & $3.867^{\mathrm{b}}$ \\
Moisture (\%) & $8.346^{\mathrm{b}}$ & $7.800^{\mathrm{ab}}$ & $6.257^{\mathrm{a}}$ & $11.450^{\mathrm{c}}$ \\
Ash (\%) & $4.218^{\mathrm{a}}$ & $6.884^{\mathrm{a}}$ & $4.674^{\mathrm{a}}$ & $4.294^{\mathrm{a}}$ \\
Protein (\%) & $81.851^{\mathrm{c}}$ & $67.987^{\mathrm{a}}$ & $78.077^{\mathrm{b}}$ & $79.144^{\mathrm{b}}$ \\
Fat (\%) & $5.148^{\mathrm{c}}$ & $3.438^{\mathrm{b}}$ & $1.938^{\mathrm{a}}$ & $4.461^{\mathrm{c}}$ \\
Total plate count (cfu/g) & $4.20 \times 10^{3 \mathrm{~b}}$ & $2.76 \times 10^{3 \mathrm{ab}}$ & $1.79 \times 10^{3 \mathrm{a}}$ & $1.24 \times 10^{3 \mathrm{a}}$ \\
\hline
\end{tabular}

Remarks AQ (distilled water), AS (citric acid), AJ (lime acid), AA (acetic acid)

The numbers followed by the same letter in the same line are not significantly different at $\alpha_{0.05}$

Table 2. Grade quality of fish meal (SNI 01-2715-1992)

\begin{tabular}{lccc}
\hline Chemichal Composition & Grade I & Grade II & Grade III \\
\hline \hline Moisture content (\%) max & 10 & 12 & 12 \\
Crude protein (\%) min & 65 & 55 & 45 \\
Crude fiber (\%) max & 1,5 & 2,5 & 3 \\
Ash (\%) max & 20 & 25 & 30 \\
Fat (\%) max & 8 & 10 & 12 \\
Ca (\%) & $2,5-5,0$ & $2,5-6,0$ & $2,5-7,0$ \\
P(\%) & $1,6-3,2$ & $1,6-4,0$ & $1,6-4,7$ \\
NaCl (\%) max & 2 & 3 & - \\
Salmonella (in 25 g/sampel) & Negatif & Negatif & Negatif \\
Organoleptic, minimum value & 7 & 6 & 6 \\
\hline
\end{tabular}

The acid solvent types used in the extraction process statistically affected the yield value of fish meal. The yield value of fish meal showed that the solvent played an important role on the yield value of products resulted from the extraction. The higher the yield value showed, the more the solvent used showed the same polarity with most material biomass (Sani et al., 2014).

Litaay \& Santoso (2013) reported that, the yield of skipjack fish meal with the treatment method and immersing period between 38.79 - $43.95 \%$ and explained that the fish meal immersed in water had a higher yield, when compared to that immersed in acid and alkali. That result had a higher yield value than that in the present research which was only $21.910-27.077 \%$, while the fish meal extracted using acid solvent had a higher yield value when compared to that extracted with the distilled water.

\section{Bulk density}

Bulk density was the size of material mass amount per the occupied volume including empty room between materials (Rusmono et al., 2016). Bulk density might be used as the characterization parameter of powder material particles, since single particle significantly influenced the product characters, such as particle size, shape, surface, 
density, hardness and adsorptive character. Bulk density of powder food product depended to a great extent on its particle size and distribution (Barbosa-Cánovas et al., 2005). A very small change in powder bulk density might result in a great flow-ability (Levy \& Kalman, 2001). Bulk density might also be utilized as the completeness parameter of drying process or material shape and size uniformity. The fast drying process might result in smaller bulk density when compared to the slow drying process.

The bulk density values of fish meal (Table 1) were $0.867 \mathrm{~g} / \mathrm{ml}$ (AQ); $0.037 \mathrm{~g} / \mathrm{ml}$ (AS); $0.937 \mathrm{~g} / \mathrm{ml}(\mathrm{AJ})$; and $0.933 \mathrm{~g} / \mathrm{ml}(\mathrm{AA})$, with the highest value in fish meal AJ and the lowest in fish meal AS. The bulk density of fish meal statistically showed that acid solvent types affected the bulk density of the product. Bulk density describes a material's particle shape and size (Atmaka \& Sigit, 2010). Based on the average value of bulk density, it showed that the fish meal AJ particle size was smaller when compared to the others with big bulk density. Meanwhile, the fish meal AS particle was bigger and had spores that resulted in small bulk density. Bulk density always paid attention to the material porosity since the smaller the bulk density, the more pores the resulted powder had indicating that the cavities between the material particles were filled with air (Jufri $\boldsymbol{e t}$ al., 2006).

\section{Whiteness}

Color is an important attribute characteristic of food materials (Dewi et al., 2012), since the material color might influence the acceptance level of a material. The whiteness level measurement of a flour product was a parameter made to determine the brightness of flour color since flour generally had different brightness levels (Hutching, 1999). The whiteness level measurement scale was $0-100 \%$ from black $(0 \%)$ to white $(100 \%)$.

The values of fish meal's whiteness level (Table 1) were as follows: $22.333 \%$ (AQ); $29.900 \%$ (AS); 33.967\% (AJ); and 30.200\% (AA) with the highest value in fish meal AJ and the lowest in the control flour (AQ). The acid solvent types used in the extraction process affected the whiteness level of fish meal.

The whiteness level of a product was affected by the raw material color and solvent type used. The whiteness level of fish meal in this research ranged between 22.333$33.967 \%$, meaning that the resulted fish meal had low whiteness level. The extraction made with distilled water resulted in fish meal with the whiteness level of $22.333 \%$. This showed that the heating and watering process might reduce the tuna red meat color, with lower effectiveness when compared with extraction using acid solvent. The result of this research was in accordance with the research conducted by Dewi et al. (2012), stating that the extraction using acid solvent significantly affected the control of whiteness level.

\section{The pH value}

The $\mathrm{pH}$ value was the value stating the acidity or alkalinity level of a solution. Product was considered acid if $\mathrm{H}^{+}$ion was dissolved in greater amount than $\mathrm{OH}^{-}$ion within a solution (Nugroho et al., 2018). The $\mathrm{pH}$ testing of fish meal was conducted to reveal the effect of acid solvent types used for extraction process on the resulted $\mathrm{pH}$ value of product.

The $\mathrm{pH}$ value of fish meal in this research respectively ranged between 2.50 5.27as follows: 5.267 (AQ); 2.500 (AS); $3.600(\mathrm{AJ})$; and 3.867 (AA) with the highest value in fish meal control (AQ) and the lowest in fish meal AS (Table 1). The acid 
solvent types used effected the resulted $\mathrm{pH}$ of fish meal since effected by the acidity level of used solvent.

\section{Proximate Analysis}

Proximate analysis was the examination conducted to reveal the nutritional composition and energy from the food material or certain product by estimating the relative amount of food materials' nutritional substances, such as moisture content, ash, protein, and fat (Table 1).

\section{a. Moisture content}

The moisture content of food varies depending on the water contained in the food products. Furthermore, food moisture content determines the food quality and endurance. Food products with low water content have longer endurance when compared to those with higher water content. Hence, food water measurement is greatly required to uniformly calculate the composition of other substances in the dried weight or known as total solids (Nielsen, 2009).

Results showed that, the moisture content of fish meal ranged between 6.257$11.450 \%$, with the value of $8.346 \%$ (AQ); $7.800 \%$ (AS); $6.257 \%$ (AJ); and $11.450 \%$ (AA), while the highest level was recorded in flour AA and the lowest in flour AJ (Table 1). The acid solvent types affected the moisture content fish meal. The extraction process using the acid solvent caused a decline in the water extracted from the fish meat's cellular tissues, hence, the fish meal's moisture content was reduced. The extraction using acid solvent might reduce the ability of gel formation in the fish meat, that when getting dried in the easily-to-lose water from the fish meat tissues. The good quality of fish meal that had moisture content was 6-10\%, since in that moisture content, damage rarely happened which might be resulted from the microbial activities (Kurnia \& Purwani, 2008). The resulted moisture content of fish meal in this research had met the best quality of fish meal standard ranging between $6.25-11.45 \%$.

\section{b. Ash content}

The ash content is usually utilized to estimate the total minerals in a food material. The minerals in ash are in the form of sulfate, phosphate, nitrate, chloride and others (Fennema, 1996). Food material are consisted of the combination of organic and inorganic components, yet when burned the organic elements $(\mathrm{C}, \mathrm{H}, \mathrm{O}$ and $\mathrm{N})$ would be lost, and the remaining was the inorganic components in ash called mineral.

The ash content (Table 1) of fish meal respectively ranged between 4.218-6.884\%, as follows: $4.218 \%(\mathrm{AQ})$; $6.884 \%(\mathrm{AS}) ; 4.674 \%$ (AJ); and $4.294 \%$ (AA), while the highest value was in fish meal AS, and the lowest was in control fish meal (AQ). The acid solvent types affected the ash content of fish meal.

The fish meal resulted from the extraction using citric acid solvent (AS) had a high ash content when compared to that in control fish meal, yet it was not in accordance with the result of research conducted by Sundari (2015) who stated that, the product resulted from the boiling process has a lowering ash content since heating process during extraction causes most minerals to dissolve in the solvent used, and in turn, the ash content becomes low. 


\section{c. Protein}

Protein content consisted of macro-nutritional energy sources has an essential role in bimolecular formation. Protein is a complex polymer composed of some amino acids (Fennema, 1996). The protein content of fish meal respectively ranged between 67.987$81.851 \%$, with the following values: $81.851 \%$ (AQ); $67.987 \%$ (AS); 78.077\% (AJ); and $79.144 \%$ (AA), while the highest value was recorded in fish meal AQ and the lowest in fish meal AS (Table 1). The utilization of acid solvent in the extraction process decreased the protein content of fish meal since acid had the ability to hydrolyze protein in the fish meat that might dissolve in the acid solvent and be wasted in the filtering process.

The protein content of fish meal increased being influenced by the $\mathrm{pH}$ level of solvent used for extraction, as the lower the solvent' $\mathrm{pH}$ is, the lower the fish meal's protein content might be resulted. Besides, there were some other factors influencing the fish meal's protein content, such as temperature, length of time, and processing method. Puwaningsih (2015) stated that the processing that utilizes steaming method result in products with higher protein content when compared to those resulted from boiling method.

The acid solvent types significantly affected the fish meal's protein content as its resulted protein contents were different as presented in Table (1). The fish meal's protein content showed that the hydrolysis ability of citric acid was stronger than that of the other acid solvents. Meanwhile, the hydrolysis ability of lime acid solvent and acetate acid showed no difference when extraction process was conducted with distilled water.

\section{d. Fat}

The fat content of fish meal respectively ranged between $1.938-5.148 \%$, as follows: $5.148 \%$ (AQ); 3.438\% (AS); $1.938 \%$ (AJ); and 4.461\% (AA), with the highest value in control fish meal AQ and the lowest in fish meal AJ (Table 1). The fat content of fish meal in this research was adequately high since assumed that the red meat used had experienced fat oxidation during the distribution process and frozen storage. Bragadottir et al. (2007) stated that the oxidized raw materials may result in low quality end-product since the fish meal's stability and quality are influenced by temperature and storage duration.

The acid solvent types used for extraction affected the fat content of fish meal that the resulted fat contents were various. This result showed that the lime acid solvent had stronger ability to reduce the fat content than the others. The extraction using the acid solvent types in high temperature might hydrolyze the fat content found in the fish meal extracted using acetate acid solvent (flour AA), since its fat content was not different compared to that in the control fish meal (AQ).

Good fish meal has fat content of $\leq 12 \%$ since fat content greatly affect the quality (Kurnia \& Purwani, 2008). The fish meal with low fat content was uneasy to experience quality decrease and rancidity. High fat content could make the fish meal easy to rancid caused by the fat oxidation. Drying in high temperature might result in higher fat oxidation in food material when compared to that in low temperature. 


\section{Total Plate Count}

Total plate count (TPC) testing was one method indirectly used to determine the number of microbes in food product by calculating the living microbes within media. This test parameter was commonly used as the general indicator explaining the food contamination level. TPC was defined as the number of colony forming unit (cfu) of bacteria in each gram or each food milliliter (Puspandari \& Isnawati, 2015). Based on SNI 7388-2009, what was meant by TPC was the number of mesophilic aerobic microbes found in per gram or per milliliter sample determined through standard method (BSN, 2009).

The TPC value of fish meal ranged between $1.24 \times 10^{3}-4.20 \times 10^{3} \mathrm{cfu} / \mathrm{g}$, respectively with the following values: $4.20 \times 10^{3} \mathrm{cfu} / \mathrm{g}(\mathrm{AQ}), 2.76 \times 10^{3} \mathrm{cfu} / \mathrm{g}(\mathrm{AS}), 1.79$ $\mathrm{x} 10^{3} \mathrm{cfu} / \mathrm{g}(\mathrm{AJ})$ and $1.24 \times 10^{3} \mathrm{cfu} / \mathrm{g}$ (AA). The extraction using different acid solvent types effected the TPC values of fish meal. The TPC value of resulted fish meal in Table (1) indicate that the acetate acid, lime acid and citric acid solvents had the same ability in inhibiting the bacterial growth in fish meal when compared to that resulted from the distilled water solvent.

Acid solvent types used in the extraction process might inhibit the bacterial growth found in tuna dark meat shown with the TPC value of fish meal which still met the standard of BSN (2006), with the minimum standard of $<2500-65.000 \mathrm{cfu} / \mathrm{g}$. The microbial growth in food content is influenced by the moisture content of food, water activity (aw) and $\mathrm{pH}$ (Atma, 2016). The $\mathrm{pH}$ of fish meal and moisture content values respectively ranged between $2.500-5.267$ and $6.257-11.450 \%$ that were able to inhibit the microbial growth in the fish meal products.

\section{CONCLUSION}

The fish meal making process using extraction method in acid solvent showed that acid solvent types affected the physicochemical characteristics of fish meal resulted in all test parameters including yield value, bulk density, whiteness level, $\mathrm{pH}$, water content, ash, protein, fat and total plate count.

\section{REFERENCES}

Afrianto, E. and Liviawaty, E. (2005). Fish feed. Kanisius. Yogyakarta [In Indonesian]

AOAC [Association of Official Analytical Chemist] (2005). Official Methods of Analytical of The Association of Official Analytical Chemist. Washington, DC: AOAC.

Atma, Y. (2016). Angka Lempeng Total (ALT), Angka Paling Mungkin (APM) dan Total Kapang Khamir sebagai Metode Analisis Sederhana untuk Menentukan Standar Mikrobiologi Pangan Olahan Posdaya. Jurnal Teknologi, 8(2): 77-82. ISSN: 2085-1669. jurnal.umj.ac.id/index.php/jurtek e-ISSN: 2460-0288.

Atmaka, W. and Sigit, B.A. (2010). Kajian Karakteristik Fisikokimia Tepung Instan Beberapa Varietas Jagung (Zea mays L.). Jurnal Teknologi Hasil Pertanian, 3(1): 13-20. 
Barbosa-Canovas, G.V.; Ortega-Rivas, E.; Juliano, P. and Yan, H. (2005). Food Powder: Physical properties, processing, and functionality. Bulk Properties pp: 55-90. Food Engineering Series.

Bertoldi, F.C.; Santanna, E.S. and Beirao, L.H. (2004). "Reducing the bitterness of tuna (Euthynnus pelamis) dark meat with Lactobacillus caseisubsp". Casei ATCC393. Food Technology and Biotechnology, 42 (1): 41-45.

Bragadottir, M.; Reynisson, E.; Porarinsdottir, K. and Arosan, S. (2007). Stability of Fish Powder Made from Saithe (Pollachius virens) as Measured by Lipid Oxidation and Functional Properties. Jurnal of Aquatic Food Product Technology, 16(1): 115-136. doi:10.1.300/J030v16n01_09

BSN (2006). SNI 06-2388-2006. Nutmeg oil. Indonesia Standardization Board.

BSN (2009). SNI 7388:2009. Maximum limit of microbial contamination in food. Indonesia Standardization Board.

BSN (2015). SNI 2332.3:2015. MRI-biological test method-part 3: determination of total plate figures (alt) in fishery products. Indonesia Standardization Board.

Dewi, N.S.; Parnanto, N.H.R. and Ridwan, A.A. (2012). Karakteristik Sifat Fisikokimia Tepung Bengkuang (Pachyrhizus erosus) Dimodifikasi Secara Asetilasi Dengan Variasi Konsentrasi Asam Asetat Selama Perendaman. Jurnal Teknologi Hasil Pertanian, 5(2): 104-112.

Fennema, O.R. (1996). Food Chemistry. $3^{\text {rd }}$ edition. Marcel Dekker, Inc. New York Basel.

Hutching, J.B. (1999). Food Color and Apearance. Apsen Publisher Inc.Maryland.

Jufri, M.; Dewi, R.; Ridwan, A. and Firli. (2006). Studi Kemampuan Pati Biji Durian Sebagai Bahan Pengikat dalam Ketoprofen Secara Granulasi Basah. Jurnal Ilmu Kefarmasian., 3(2): 78-86. ISSN: 1693-9883.

Immaculate, K.J.; Velammal, A. and Patterson, J. (2013). Utilization of Trash Fishes as Edible Fish Powder and its Quality Characteristics and Consumer Acceptance. World Journal of Dairy \& Food Sciences, 8(1): 01-10. 2013 ISSN 1817-308X IDOSI Publications, doi: 10.5829/idosi.wjdfs. 2013.8.1.7123

Karunaratha, K.A.A.U. and Attygalle, M.V.E. (2010). Nutritional evaluation in five species of tuna Vidyodaya. Journal of Science, 15(1 \& 2): 7-16.

Kurnia, P. and Purwarni, E. (2008). Pemanfaatan Ikan Kembung Sebagai Bahan Baku Tepung Ikan Ditinjau Dari Kadar Abu, Air, Protein, Lemak Dan Kalsium. Jurnal kesehatan, 1(1): 39-46. ISSN 1949-7621.

Lanier, T.C.; Hart, K. and Martin, R.E. (1991). A manual of Standard Methods for Measuring and Specifying the Properties of Surimi. Washington, DC: National Fisheries Institute.

Levy, A. and Kalman, H. (2001). Handbook of Conveying and Handling of Particulate Solid. Handbook of Powder Technology. Amsterdam. Elsevier Science B.V. 
Litaay, C. and Santoso, J. (2013). The effects of different immersion method and time on physic-chemical characteristics of skipjack tuna (Katsuwonus pelamis) fish meal. Jurnal Ilmu dan Teknologi Kelautan Tropis, 5(1): 85-92.

Martinez, I.; Santaella, M.; Ros, G. and Periago, M.J. (1998). Content and in vitro availibility of Fe, $\mathrm{Zn}$ and $\mathrm{P}$ in homogenized fish-base weaning food after bone addition. Food Chem., 63: 299-305.

Nielsen, S.S. (2009). Determination of Moisture Content. Food Science Texts Series book series (FSTS). Food Analysis Laboratory Manual pp. 17-27.

Nugroho, P; Dwiloka, B. and Rizqiati, H. (2018). Yield, $\mathrm{pH}$ value, texture, and antioxidant activity of fresh cheese with acid Roselle Purple Flower extract (Hibiscus sabdariffa L.). Jurnal Teknologi Pangan 2(1): 33-39. [In Indonesian]

Okada, M. (1990). Fish and Raw Material. In science of Processing Marine Food Product. Vol. I. editor. T. Motohiro, H. Kadota. K. Hashimoto. M. Katayama and T. Tokunaga. Japan International Coorporation Agency. Hyoga International Centre Japan.

Purwaningsih, S.; Suseno, S. H.; Salamah, E., Mulyaningtyas, J. R. and Dewi, Y. P. (2015). Effect of boiling and steaming on the profile fatty acids and cholesterol in muscle tissue of molluscs. International Food Research Journal 22(3): 1087-1094.

Puspandari, N. and Isnawati, A. (2015). Description of The total plate count results in several infant formula. Jurnal Kefarmasian Indonesia, 5(2): 106-112. ISSN: 2085-675X e-ISSN: 2354-8770.

Rusmono, M.; Nasution, M.Z.; Herdiana, N., and Maryani, A. (2016). Pengolahan Hasil Pertanian. Edisi 2. Modul 1-9. Universitas Terbuka. Tanggerang.

Sánchez-Zapata, E.; Amensour, M.; Oliver, R.; Fuentes-Zaragoza, E.; Navarro, C.; Fernández-López, J.; Sendra, E.; Sayas, E. and Pérez-Alvarez,J.A. (2011). Quality Characteristics of Dark Muscle from Yellowfin Tuna (Thunnus albacares) to Its Potential Application in the Food Industry. Food and Nutrition Sciences, 2: 22-30. doi:10.4236/ fns.2011.21003

Sani, R.N.; Nisa, F.C.; Andriani, R.D. and Maligan, J.M. (2014). Analisis Rendemen dan Skrining Fitokimia Ekstrak Mikroalga Laut (Tetraselmis chuii). Jurnal Pangan dan Agroindustri, 2(2): 121-126.

Singh, N.; Kaur, L.; Sondhi, N.S. and Sekhon, K.S. (2005). Physochemical coocking and textural properties of milled rice from different Indian rice cultivars. Food Chem., 89: 253-259.

Stone, R. (2007). A Business Manual on Value Added Products from Tuna and by Catch Tuna. Development of tuna fisheries in Pacific ACP countries (DEVFISH) project. European Union, Brussel, Belgium.

Sundari, D.; Almasyhuri; and Astuti, L. (2015). The effect of cooking process on the composition ofnutrients for food'sprotein source). J. MediaLitbangkes. 25(4): 235-242. [In Indonesian] 